\title{
Olaf Du Pont
}

Hogeschool Gent and Universiteit Gent

\section{BUT WE'RE AMERICAN... THE PRESENCE OF AMERICAN EXCEPTIONALISM IN THE SPEECHES OF GEORGE W. BUSH}

\begin{abstract}
This paper defines American exceptionalism as the notion held by Americans that their country is unique and has a specific role to play in the world. The origins of this notion are traced to $17^{\text {th }}$ century Puritan settlers, who used the metaphor of being "a city upon a hill" to highlight their position as a moral example to the rest of the world. This element from a sacral religion was transformed during the founding of the United States into an element of civil religion, and as such the metaphor and concept of American exceptionalism received a political connotation. The rise of America's political power coincided with a more active role in world politics, which was backed with a rhetoric emphasising unity and America's unique role. The clash between the passive and the more active reading of the exceptionalist metaphor and the struggles between sacral and civil religion coincide during the presidency of George W. Bush. The presence of these elements of political rhetoric is surveyed in a corpus of speeches by President Bush.
\end{abstract}

\section{Keywords}

Exceptionalism, Puritan, sacral and civil religion, USA, exceptionalist metaphor, G.W. Bush.

\section{Introduction}

The concept of American exceptionalism refers to a double notion that is commonly associated with the United States and its history. General reference works that aim to describe American society define the concept by focusing on its historical roots and on the current interpretation of this notion. First, the historic roots of American exceptionalism date back to the Protestant belief of being a 
society that has a pact with God and that acts as a moral example to the world. Second, American exceptionalism is the current feeling that America as a country is unique and that it is essentially different from any other country (Mauk and Oakland 1997). This paper tries to highlight how the two concepts are linked by surveying how the original concept of American exceptionalism evolved through time. Emphasis is put both on the notion of civil religion versus sacral religion and on the notion of sovereignty of human and civic rights. The presence of the rhetoric of American exceptionalism in speeches by George W. Bush will be illustrated and offset against earlier speeches by American politicians to assess whether the current political rhetoric is a natural continuation of an ongoing process or a radical shift away from a tradition of American political rhetoric.

\section{The roots of American exceptionalism}

The term American exceptionalism was coined by Alexis de Tocqueville (Rogers 1998; Mohlo and Woods 1998; Rios 2003), a French citizen who travelled through the United States in the early $19^{\text {th }}$ century. De Tocqueville used the term to describe the sense of uniqueness and mission that he encountered among American citizens. The ideas that form the basis of American exceptionalism can be traced to the first settlers. In 1630, a fleet of Puritans headed by John Winthrop landed in America and to mark the occasion, the to-be governor of the Massachusetts Bay Colony delivered a sermon, A Model of Christian Charity. This speech introduced the basic tenets of American exceptionalism into American political rhetoric. The double position of John Winthrop as both a pastor and a politician partly accounts for the influence of religious elements on political rhetoric.

Winthrop described America as a promised land that was given to the settlers as an opportunity for them to lead a moral life in accordance with the will of God. In rejecting the morally-flawed ways of Europe and by adhering to God's laws, America would be "a city upon hill." This notion of being an example was not a given, but was conditional upon the strict adherence to the will of God and this agreement was sealed in a covenant with God. If the moral example was not upheld, the settlers risked God's wrath. To implement such a future-oriented project, unity and obedience were required. In order to ensure this bond, Winthrop emphasized the need for charity and justice from the rich on behalf of the poor. By exercising compassion, society could prosper; a society which was primarily founded on the notion that all people are not equal:

God Almighty in his most holy and wise providence, hath soe disposed of the condition of mankind, as in all times some must be rich, some poore, some high and eminent in power and dignitie; others mean and in submission. [...] For wee must consider that wee shall be as a citty upon a hill. The eies of all people are uppon us. 
(John Winthrop -1630, published 1838).

Next to the Puritan settlements headed by John Winthrop, many other colonists set up in the new World and sometimes held differing views on matters of state and religion (Kaufman 1999; Murray 2005). Despite the influence of these groups on political ideas, none of their founding texts ever equalled the impact of Winthrop's speech on later generations when it comes to its rhetoric devices.

\section{The continuing influence of the rhetoric of John Winthrop}

Three hundred and seventy-five years after John Winthrop made his seminal speech, the very biblical metaphor he borrowed to describe what America should aspire to be has a wide currency in American political rhetoric: a city upon a hill.

President Reagan spoke of America as the shining city on a hill. I see California as the golden dream by the sea.

(Arnold Schwarzenegger-17 November 2003-Inaugural Address)

We are defined as Americans by our beliefs-not by our ethnic origins, our race or our religion. Our beliefs in religious freedom, political freedom, and economic freedom-that's what makes an American. Our belief in democracy, the rule of law, and respect for human life-that's how you become an American. It is these very principles-and the opportunities these principles give to so many to create a better life for themselves and their families-that make America, and New York, a "shining city on a hill."

(Rudy Giuliani-1 October 2001-Opening Remarks to the United Nations General Assembly Special Session on Terrorism)

Other elements such as referring to a covenant and the idea of guiding providence are also features that were present in Winthrop's speech and that reoccur in today's political speeches by both Republicans and Democrats. Bill Clinton ran for President on a policy of creating a New Covenant with the people in 1992, and George W. Bush refers to the concept of guiding Providence in his speeches. Charles Haynes of the First Amendment Center even goes so far to state that no President can get elected without making some sort of reference to the ideas in Winthrop's speech (Charles Haynes, quoted in Murray 2005). As such the speech can be labelled the founding text of American political rhetoric. The following section highlights how elements from a sacral religion, in this case $17^{\text {th }}$ century Puritanism, can remain current in modern political rhetoric. 


\section{Shifting interpretations of "a city upon a hill": birth of a civil religion}

The main shift in the interpretation of the metaphor of America as a shining example for the rest of the world came with the organic growth of a civil religion following the Declaration of Independence at the end of the $18^{\text {th }}$ century. The Founding Fathers merged the ideas of American exceptionalism into a civil religion by using the metaphors and ideas of being a moral example and fit them into the political context of the day. Whereas John Winthrop saw his city on a hill as a moral example that was constantly threatened by a Christian God, the Founding Fathers were faced with a more delicate balancing act. They had to create a system that checked and balanced many political and religious concerns: not only did the power of the various states and interest groups have to be balanced, also the influence of different religious denominations had to be weighed (Steinmo 1994). By introducing the concept of separation of Church and State, the Founding Fathers made sure that no one denomination could gain the upper hand. A religious dimension was still felt as necessary, however, and here the concept of a civil religion proved valuable. By opting for an overarching civil religion that was broad enough to cover all existing denominations and that required no specific rites or referred to doctrinal texts, separation of Church and State was maintained and a moral foundation could be secured (McClay 2004). The first sentence of the Declaration of Independence gives us a telling example of the balancing of different religious views. Thomas Jefferson first wrote: We hold these truths to be sacred, but later changed sacred to self-evident in an attempt to keep the declaration denomination-neutral (Mason 2005). The influence of moral arguments cannot be underestimated as Smith (1995) claims that the people were more easily persuaded to rise against the British throne by religious arguments than by political ones.

As such, a political compromise was reached that limited the direct influence of a specific God, and imposed the indirect function of a Creator, who had created mankind to his image and had endowed man with unalienable rights. The denomination-neutral character of the Creator enabled the Founding Fathers to keep the preceding sources of American political rhetoric and thinking intact, while allowing for enough flexibility to accommodate differing views. By not referring to names such as "Jesus" or "Christ" and by not imposing doctrinal texts or rites, a civil religion was invented that could easily be transferred upon different denominations (Bellah 1967; McClay 2004). The founding political texts-the Declaration of Independence, the Constitution, the Bill of Rights-and semi-rites and commemorative events, such as the Pledge of Allegiance to the Flag, Memorial Day, the $4^{\text {th }}$ of July, can, however, function as expressions of this civil religion (Bellah 1967; McClay 2004). This uniting form of civil religion gave rise 
to a united form of Protestantism that allowed for the easy assimilation of newcomers in the Anglo-Saxon culture of the original settlers (Kaufman 1999).

Civil religion is a means of investing a particular set of political and social arrangements with an aura of the sacred, thereby elevating their stature and enhancing their stability. It can serve as a point of reference for the shared faith of an entire nation. As such, it provides much of the social glue that binds together a society through well-established symbols, rituals, celebrations, places, and values, supplying the society with an overarching sense of spiritual unity-a sacred canopy, in Peter Berger's words - and a focal point for shared memories of struggle and survival. Although it borrows extensively from the society's dominant religious tradition, civil religion is not itself highly particularized but instead is somewhat more blandly inclusive: People of various faiths can read and project what they wish into its highly general stories and propositions. It is, so to speak, a highest common denominator. (McClay 2004: 36)

In a way, the drafting of the Declaration of Independence and the Constitution mirrored the time of the first settlers. In both cases a new project was under threat and society needed to be united to ensure its survival. In 1776, the threat was no longer God's wrath but the military might of an imperial superpower. The fragile United States survived the Revolutionary War and its internal political differences and started to live out its name as "united states." This focus on unity is still present at moments of potential division, as Robin Lakoff illustrated when comparing the concession speech of Al Gore to the acceptance speech by George W. Bush in the 2000 presidential elections and found a remarkable emphasis on a need for unity that transcends partisan feelings (Lakoff 2001).

The rhetoric of a civil religion and its use for ceremonial functions strengthens a feeling of national unity. The emphasis on a common cause with ancestors is not unique for American society, but a trait of any form of nationalistic rhetoric (Bishop and Jaworski 2003). For American exceptionalism and its civil religion, the emphasis on continuity shows both in the explicit mentioning of American political heroes, and in the rewording of their famous sayings. President George W. Bush mentioned Thomas Jefferson 37 times, George Washington 32 times and Abraham Lincoln 116 times in official speeches in the period from 20 July 2001 until 31 December 2004, according to the online collection of speeches and public statements by George W. Bush on www.vote-smart.org. As for rephrasing famous quotes by American political heroes, President Bush said in his Second Inaugural Speech that freedom is the permanent hope of mankind, paraphrasing Abraham Lincoln's famous quote: America is the last best hope of mankind.

\section{Sovereignty of law in a civil religion}


By offering an implicit civil religion that serves as the basis for the political framework of the new nation, the founding fathers avoided creating a state religion and upheld the separation of church and state. A moral basis for the laws of the country still depended on a divine entity, however, and in this respect the American Revolution differs significantly from the French Revolution. In France, the revolution was a reaction against an unjust system of an absolute monarch who was supported by the Church, and by extension by God. In removing the source of injustice, the King, the people had to rid themselves of the source of the monarch's power: God, to achieve freedom. America saw the Creator, God, as the source of freedom, not as an impediment to it. Europe and America adhere to different concepts of the sovereignty and the origin of human rights, with on the one hand the European will of the people and on the other the American concept of rights as a divine gift. Roger Bellah wrote in his ground-breaking essay "Civil Religion in America" (1967):

In American political theory, sovereignty rests, of course, with the people, but implicitly, and often explicitly, the ultimate sovereignty has been attributed to God. [...] Though the will of the people as expressed in the majority vote is carefully institutionalized as the operative source of political authority, it is deprived of an ultimate significance. The will of the people is not itself the criterion of right and wrong. There is a higher criterion in terms of which this will can be judged; it is possible that the people may be wrong. The president's obligation extends to the higher criterion. (Bellah 1967: 4)

This different concept of absolute sovereignty is masked by using the same rhetoric (freedom, liberty) on both sides of the Atlantic Ocean and by inferring similar practical implications for human rights and freedom from different starting points. The notion of different sovereignty sources is not always clear to Europeans, who focus on the common rhetoric of freedom and liberty. Western thinking about the source of human rights gets contrasted with, for instance, Muslim sources of rights, without acknowledging the inherent divine source of America's concept of human rights (Hermann 1999). Inversely, Muslim authors, such as Zulhuda, reckon that all Western law is man-made.

Cette recherche a pour objectif la compréhension de la logique générale qui a commandé les différents discours des auteurs occidentaux et musulmans sur le sujet en question. [...] Quand, en Occident, les normes relatives aux droits de l'Homme sont dérivées de la Magna Carta britannique, de la Révolution française ou des principes de la Déclaration américaine d'indépendance, dans les Etats musulmans, elles s'appuient sur le Coran et sur les faits et gestes du Prophète; ce sont là les sources, le langage et le vocabulaire normaux de la pensée musulmane. (Hermann 1999, online) 
DOI 10.2478/v10016-007-0008-5

The Universal Declaration of Human Rights is very much colored by the concept of natural law from the Greek philosophy, while the Cairo Declaration is based on the Islamic concept and Islamic worldview. In the former, man-made law is the source, while in the latter it is divine law that serves as the source of human rights. (Zulhuda 2005 , online)

A number of scholars such as Jack Donnelly deny a divine source for human rights, but see them arise from human action (2002). Alan Dershowitz (2004) sees the source of natural rights not in religion or law but in the experience people have with injustices. Because of the various sources of sovereignty, the Universal Declaration of Human Rights was drafted in such a way that the origin of inalienable rights was not defined, but that their existence was accepted by all parties.

These various ideas were captured in the Universal Declaration of Human Rights adopted by the United Nations (UN) General Assembly in 1948, which states that "recognition of the inherent dignity and of the equal and inalienable rights of all members of the human family is the foundation of freedom, justice and peace in the world." (Rights and Humanities 2003, online)

The ability of America's civil religion to unite and to provide a source of legitimacy for laws and rights has been outlined by Wilfred McClay (2004) and Bruce Murray (2005). McClay and Murray trace the origin of a civil religion back to Antiquity and more modern interpretations of the concept by Rousseau. In his comments, McClay remarks that by incorporating civil religion into a political system, one can implicitly rank civil legislation below divine laws. Recent events illustrate this possibility: Alabama Chief Justice Roy S. Moore said in his testimony before the state of Alabama Court of the Judiciary (case no. 33) on his removal from the bench after refusing to remove a statue displaying the Ten Commandments from his court: "The people of this state elected me as Chief Justice to uphold our Constitution, which establishes our justice system on the invoking the favor and guidance of Almighty God. To do my duty, I must acknowledge God. That's what this case is about." This example shows that the sovereignty of American law can be judged by some to come second to religious teachings within the system of American civil religion. McClay warns against this danger because of its intrinsic divisive character: if devote worshippers of a religion feel that the laws that are upheld by a form of civil religion do not conform to their personal religious beliefs, they may distance themselves from the civil religion and the laws it imposes. Consequently, civil religion, a system that was devised to counter division, can become the downfall of the union because of a too great a rift between secular and religious groups in society. Roger Bellah (1967) 
described this possible tension, but thought at the time that the differences were limited.

\section{Civil religion criticised}

Critics of civil religion and its link with American exceptionalism are many: Roger Bellah, who applied the concept of civil religion extensively for the United States (1967) has mixed feelings on the topic because of the pernicious outcome that any policy could have if it is warranted by reverting to a-by definition-moral superiority of the American nation. The Civil War illustrates this tendency: at a time when the survival of the Union and of the project America was at stake, both sides claimed to act in accordance with the will of God. In his Second Inaugural Address, Abraham Lincoln criticised this tendency of claiming God's support to warrant policies. He went on to emphasise that only God chooses who acts on his behalf, no man can claim God's blessing. However, by claiming to continue the project started by the Founding Fathers in a moment of threat to that project, and by referring to common hardships during the war on both sides, Lincoln strengthened the concept of a civil religion and reintroduced an idea of selflessness that was present in John Winthrop's speech and that would reoccur later in the Inaugural Speech by John F. Kennedy "Ask not what your country can do for you, but what you can do for your country." Lincoln's assassination only strengthened this image and reinvigorated the concept of suffering and overcoming ordeal as part of America's civil religion (Bellah 1967).

The moral cause for the Civil War can be linked to the notion of being a moral example to 1860's domestic politics: for some God's wrath had to be feared because slavery could not be reconciled with God's teachings (Murray 2005). Applying a moral example to domestic affairs had almost meant the end of America as a project. From the second half of the $19^{\text {th }}$ century, the moral strain of American exceptionalism would be mainly used for foreign policy ends. One of the founding Fathers, Hamilton, warned against the danger of claiming the moral high ground in foreign matters (Chace 2002). Then Secretary of State, John Quincy Adams added later that America should not go and look for monsters abroad in urging not to enter into an active power policy abroad (Chace 2002). Adams, however, did encourage the notion of American exceptionalism by viewing America as a "standard of freedom and independence," but merely passively, as an example. The wariness to use American exceptionalism in foreign policy is still current and voiced by Republican Pat Buchanan, who favours a non-intervention policy by the US. In Buchanan's views, the US can only be a moral example passively, not by imposing a political or moral view actively on the world (Buchanan 1999). 
Pat Buchanan's position illustrates two important features of American exceptionalism and its evolution. First, it signals that civil religion is not a partisan affair: both within the Republican party and the Democratic Party, there are both advocates of the activist interpretation of American exceptionalism and critics of active foreign policy based on a belief in America's role of champion of freedom. One can find ardent critics of civil religion within the Republican party because it diverts attention from a true religion, but also because in the name of a civil religion, too much power is attributed to the Federal government or because of an active intervention policy in foreign affair matters, which clashes with the position of being a passive moral example (Wolfson 2004). Within the Democratic party, members of the Democratic Leadership Council, such as Bill Clinton, Joe Lieberman and John Kerry, endorse civil religion and favour active involvement in foreign affairs, whereas others steer away from this position and side with other isolationists. Second, Buchanan's position shows that the increasing power of the United States has moved the country away from a foreign policy that was explicitly guided by moral principles at the time when it was a small Republic at the geographic periphery of the world to an adoption of European style power politics and real politics (Stearns 1996; Bacevich 1998; Barry 2002; Hendrickson 2002; Wolfson 2004; Murray 2005).

The aspects of the rising power of the US can best be illustrated by examining a number of quotes by foreign policy makers. During the first sustained expansion period, presidents such as William McKinley and Theodore Roosevelt would pursue America's interests abroad by using force if necessary. In doing so they used a rhetoric of moral sanctioning of their actions (Moss 2003). Mark Twain criticised the policies of the US and other "imperial" states and targeted the hypocrisy of the rhetoric "with its banner of the Prince of Peace in one hand and its loot-basket and its butcher-knife in the other" (Twain quoted in Solomon 2005). Isolationists laboured to stop the active international policies of the US, often on the moral ground that it pervaded the moral fabric of America. This critical tenet became even more pronounced after Woodrow Wilson's active involvement in bringing democracy to the world during and after the First World War. American theologist Reinhold Niebuhr argued that the automatic assumption that America acts for the good will bring about moral corruption. After the second world war, Niebuhr repeated his claim by focussing on the immoral nature of the atomic bomb and the irony that such an immoral weapon was used by a nation claiming the moral high ground over communism (1952). Although an ardent enemy of communism, Niebuhr did not refrain from highlighting similarities in potential immoral action between the US and the Soviet Union (Niebuhr 1952). He considered it a dangerous irony that a country which was born out of resistance against foreign oppression would engage in the same kind of oppression, while still keeping the same rhetoric that founded the nation. Today, the same feelings are 
present and voiced by scholars (Lipset 1996), politicians such as Pat Buchanan and citizens alike. Keith Halderman (2004) blogged on the History News Network that:

I paraphrase Abraham Lincoln when I write that America is the last best hope of mankind. He did not mean that we were to spread over the globe installing our way of life by force. He meant that we were to lead by example, to create the most free, most humane, most prosperous society possible, as a beacon for the rest of the world. We cannot do that and also do something tough about Putin's collection of more power. They are two incompatible goals.

President Wilson's emphasis on multilateral organisations to keep other powers in check was taken over by Franklin D. Roosevelt and in the aftermath of the second world war these ideas were implemented through institutions such as the United Nations and the North Atlantic Treaty Organization (Barry 2002; Kersch 2004). Within those bodies, the US tried to act as a "first-among-equals" (Hendrickson 2002). Gradually, however, the emphasis on a concerted approach lost out to a more unilateral position. A number of reasons can be put forward to account for this change in position. First, the success of "winning" the cold war had given rise to a feeling of confirmation, that the US is truly blessed because it overcame (yet another) struggle against an "evil empire" (Friedberg 2000; Barry 2002). Hoffman (2003) acknowledges that this success created "new exceptionalists" who "are no more than realists drunk with America's new might as the only superpower." The need for an outside enemy to define America has been emphasised by Barry (2002) and Samuel Huntington (2004) who intrinsically linked the need for an outside foe to fostering American exceptionalism .

Second, Leena Tomi has shown that when faced with a perceived enemy, American rhetoric adapts itself and creates stereotypes that fit an anti-ideology (2001). Roger Bellah observed this tendency when he described the anticommunist feeling as starting out as a struggle against a group of people who held opposing views but developing into a feeling of battling ideas more than people (Bellah 1967).

Third, the rise of international regulations that limit and influence American laws has increased over the past couple of years. Yet, the feeling of uniqueness, combined with a different-divine-source of sovereignty make that outside rules are not supported widely within the US. This endemic distrust for other sources of law, which do not emanate from within the US, prompt the US to steer away from international bodies and treaties, such as the Nuclear Test Ban, the International Court of Justice, the Kyoto Protocol (Barry 2002; Kersch 2004). Kersch fervently argues against adopting external sources of sovereignty, especially when it overrides American sovereignty: "[...] customary international law is binding on American judges even in direct opposition to the wishes of the nation's political branches." (emphasis in original, 2004: 6) 
Fourth, the United States military is by far the most powerful army in the world and it is an explicit policy to maintain that position indefinitely from a concern that no one should ever be able to threaten the US militarily in the future (Barry 2002; Hendrickson 2002). The notion that America is threatened never prompted the US to build up a military supremacy until after the Second World War, when instead of demilitarising, the military was strengthened. A similar situation occurred after the fall of the Soviet Union. This new policy, which is in flagrant opposition with George Washington's warnings against maintaining a standing army, fit in the idea that America is under constant threat and that absolute security has to be guaranteed (Barry 2002; Hendrickson 2002). Following Abraham Maslow's observation that if all you have is a hammer, every problem looks like a nail, it is clear why armed forces are used to solve foreign policy problems before exhausting all diplomatic means (Stearns 1996; Barry 2002).

\section{American exceptionalism in speeches by George W. Bush}

The following section deals with the elements mentioned above and tries to identify them in contemporary American political rhetoric. The intertwined relation of American exceptionalism and American civil religion has been linked by a number of scholars to special events such as inaugural and farewell speeches of presidents and linked to American holidays that play an important role in maintaining civil religion, such as the $4^{\text {th }}$ of July, Memorial Day, the birthdays of George Washington, Thomas Jefferson and Abraham Lincoln (Bellah 1967; McClay 2004). For this reason, speeches by President George W. Bush have been selected that were given to mark an occasion that celebrated American civil religion, but also speeches that link civil religion to day-to-day life, such as speeches on teaching American history and a speech to public servants.

The basis of civil religion and its use of American exceptionalism can be summarised by claiming that the founding texts of both the civil religion and of the United States outline basic and inalienable rights that derive their sovereignty from God. Robert Bellah argued that a president mentioning God is possible because "the separation of church and state has not denied the political realm a religious dimension" (1967). The divine nature of the source of human and civic rights can be discerned in a number of speeches by George W. Bush:

Those new citizens of a nation just four days old heard inspiring words, but not original thoughts. Our founders considered themselves heirs to principles that were timeless and truths that were self-evident. [...]

A wonderful country was born, and a revolutionary idea sent forth to all mankind: Freedom, not by the good graces of government, but as the birthright of 
every individual. Equality, not as a theory of philosophers, but by the design of our Creator. [...]

The founding generation discerned in that faith the source of our own rights-a divine gift of dignity, found equally in every human life.

(George W. Bush-4 July 2001)

America's vital interests and our deepest beliefs are now one. From the day of our founding, we have proclaimed that every man and woman on this earth has rights, and dignity, and matchless value, because they bear the image of the maker of heaven and earth.

(George W. Bush-29 January 2002-State of the Union 2002)

[italics added for emphasis]

In his 2001 speech to mark the Declaration of Independence, President Bush refers to the timeless nature of the ideas in the Declaration of Independence. In doing so, the drafting of that document is not seen as writing a text that is the work of a number of specific individuals in a specific time under specific circumstances, but as a wording that echoed timeless ideas. The origin of those ideas becomes clear when President Bush denies the source of those timeless ideas to man, philosophers, but attributes them to our Creator. By using the term Creator over Jesus or Christ, President Bush refers to a general deity as is customary in American civil religion. To do otherwise would be to equate Christianity to civil religion, which would violate the separation of Church and State. However, the imprint of Christianity on American civil religion is highly visible in the symbolic use of the Bible in for instance the Inauguration process, but it is also present in the rhetoric used, as can be seen in the same speech to mark the $225^{\text {th }}$ birthday of the Declaration of Independence:

The Liberty Bell has been mostly silent for two centuries. And during the Revolution, it was unseen, hidden under the floorboards of a church in Allentown. Yet, even in silence, it has always borne one message, cast for the ages with the words of the Old Testament: "Proclaim liberty throughout all the land, unto all the inhabitants thereof."

(George W. Bush-4 July 2001)

[italics added for emphasis]

By repeating a text from the Old Testament chosen by the Founding Fathers, President Bush links civil religion to a form of sacred religion. By choosing to repeat a text taken from the Old Testament and not the New Testament, the link with Christianity remains hedged, however. President Bush seems to blur the distinction between sacred and civil religion on other occasions as well. When George W. Bush was asked to name the political philosopher he identified with most during the Republican primary debate in Iowa, he replied: "Christ" and was 
later criticised for labelling Jesus Christ a political philosopher (Welch 2000). When asked during the 2004 presidential campaign what book the presidential candidates turn to for inspiration when making decisions, Bush selected the Bible, Kerry the Constitution. Kerry's position of favouring civil religion texts over sacred religion texts was endorsed by a number of renegade Republicans, who spoke out in favour of civil religion, and against the adoption of sacred religion in politics.

We are ordinary Republicans...moderate, conservative, and progressive-who believe in the sanctity of our Constitution and Bill of Rights. This unites us in our desire to return our country and our party to the traditional values that have been abandoned by the present extremist administration.

(http://inprogress.typepad.com/republicanswitchers/)

[italics added for emphasis]

By confirming the sacred status of the founding texts of the United States and by denouncing an extremist administration, these Republicans sided with civil religion, but distanced themselves from the influence of sacral religion.

Next to the divine source of human and civic rights, their universality is stressed and upheld as a standard to judge others in American civil religion.

The world still echoes with the ideals of America's Declaration. [...] They are the standard to which we hold others, and the standard by which we measure ourselves.

(George W. Bush-4 July 2001)

[italics added for emphasis]

The actions undertaken by the United States in the past and present are labelled morally in concordance with those human and civic rights. America's actions are by definition morally good actions. In addition, the uniqueness of the United States in this respect is stressed. This uniqueness is explicitly not linked to an idea of being elected to that purpose. The emphasis is placed on an indirect logic: God chooses to select people who will act morally. The success of the United States can be seen as the result of divine benevolence: God defends liberty, America defends liberty, there is more liberty, and hence God blesses America. This logic can be heard in the phrase "May God continue to bless America," which was used 78 times by George W. Bush in official speeches in the period 20 July 2001 until 31 December 2004 ("May God bless America" occurred 155 times in the same period, according to the online collection of speeches and public statements by George W. Bush on www.vote-smart.org).

Our nation has always been guided by a moral compass.

(George W. Bush-4 July 2001) 
These are extraordinary times, times of testing for our government and for our nation. Yet all of us can be proud of the response of our government, and the exceptional character of the nation we serve. I've never felt more certain about America's goodness, or more confident about America's future.

(George W. Bush-15 October 2001-President Honors Public Servants)

Whether it's been in the Revolutionary War, or the heroic struggle to end slavery, or civil rights wars in the United States Congress, or whether it's World War II where we fought to free people from tyranny, the history of this nation has been a history of freedom and justice.

(George W. Bush-17 September 2002-Remarks by the President on Teaching American History and Civic Education)

Our cause is just, and it continues. [...] And all nations should know: America will do what is necessary to ensure our nation's security. [...] We want to be a nation that serves goals larger than self. We've been offered a unique opportunity, and we must not let this moment pass.

(George W. Bush-29 January 2002-State of the Union 2002)

No nation owns these aspirations, and no nation is exempt from them. They embrace tyranny and death as a cause and a creed. We stand for a different choice, made long ago, on the day of our founding. We affirm it again today. We choose freedom and the dignity of every life.

(George W. Bush-29 January 2002-State of the Union 2002)

Not because we consider ourselves a chosen nation; God moves and chooses as He wills. We have confidence because freedom is the permanent hope of mankind, [...] History has an ebb and flow of justice, but history also has a visible direction, set by liberty and the author of Liberty.

(George W. Bush-20 January 2005-Second Inaugural Address)

[italics added for emphasis]

When faced with situations that are contradictory to the idea of America as a moral beacon, this notion is saved by labelling any immoral acts un-American. These acts are a negation of what it means to be American. This rhetoric was used by the president's aides in the aftermath of the prisoner-abuse scandal in Abu Ghraib, Iraq.

Any American who sees the photographs that we've seen has to feel apologetic to the Iraqi people who were abused and recognize that that is something that is unacceptable and certainly un-American.

(Donald Rumsfeld-5 May 2004-Good Morning America (ABC))

[italics added for emphasis] 
The emphasis on absolute security is a recurrent theme, especially after the attacks of 9/11. And all nations should know: America will do what is necessary to ensure our nation's security.

(George W. Bush-29 January 2002-State of the Union 2002)

We will persistently clarify the choice before every ruler and every nation: The moral choice between oppression, which is always wrong, and freedom, which is eternally right.

(George W. Bush-20 January 2005-Second Inaugural Address)

\section{Discussion}

The notion of American exceptionalism has changed from being a central element in an American sacral religious tradition to a central tenet of America's civil religion. These two forms of exceptionalism have existed side-by-side and continue to blur the message behind the same metaphor of being "a city upon a hill." On the one hand, there is the legacy of the sacral interpretation, which prompts Americans to be passive and give the moral example to the rest of the world. On the other, America acts as a guarantor for freedom and in doing so it can engage in active policies abroad that are automatically vindicated by its selfappointed role of the champion of freedom. External influences that could check this supremacy are discarded because these influences have no sovereignty over the American people. The rising number of events in which the lines between civil and sacral religion are blurred in domestic affairs, and the pressure to acknowledge external sovereignty are testing the flexibility of America's founding concepts and the rhetoric that embodies them. The speeches by President George W. Bush are laced with references to American exceptionalism and civil religion. These concepts are used to further and defend an active policy abroad. The rhetoric used is not a new phenomenon but merely an adaptation of existing rhetoric to changing conditions. The presence of ideas of exceptionalism provide a fertile soil for supremacist thinking.

\section{References}

Albanese, Catherine L. "American religious history: a bibliographical essay." Currents in American Scholarship Series 2003: 14-36. Washington DC: U.S. State Department Bureau of Educational and Cultural Affairs. http://exchanges.state.gov/education/amstudy/currents/ReligionCAS.pdf April 2005). 
Bacevich, Andrew J. "The irony of American power." First Things 81 (1998): 1927.

Barry, Tom. "The US power complex: what's new." Foreign Policy in Focus 2002: 20-44.

Bellah, Robert. "Civil religion in America." Daedalus 96 (1967): 1-21. http://hirr.hartsem.edu/bellah/articles_5.htm (30 March 2005).

Bishop, Hywel and Adam Jaworski. "'We beat 'em': nationalism and the hegemony of homogeneity in the British press reportage of Germany versus England during Euro 2000." Discourse and Society 14 (2003): 243-271.

Buchanan, Patrick. A Republic, not an Empire: Reclaiming America's Destiny. Washington DC: Regnery, 1999.

Chace, James. "The dilemmas of the city upon a hill." World Policy Journal 14 (1997): 55-67.

—. "Imperial America and the common interest." World Policy Journal 19 (2002): 5-19.

Dershowitz, Alan. Rights from Wrongs: A Secular Theory of the Origin of Rights. New York: Basic Books, 2004.

Dodd, Larry and Calvin Jillson, eds. The Dynamics of American Politics: Approaches and Interpretations. Boulder: Westview Press, 1994.

Donnelly, Jack. Universal Human Rights in Theory and Practice. Ithaca: Cornell University Press, 2002.

Friedberg, Aaron L. In the Shadow of the Garrison State. America's Anti-Statism and Its Cold War Strategy. Princeton: Princeton University Press, 2000.

Halderman, Keith. "No ability, no right, no responsibility." Liberty \& Power: Group Blog 2004. http://hnn.us/blogs/entries/7587.html (4 April 2005).

Hendrickson, David C. "Toward universal empire: the dangerous quest for absolute security." World Policy Journal 19 (2002): 21-36.

Hermann, Peggy. L'existence d'une conception des droits de l'homme propre aux états musulmans. Montpellier: Faculté de Droit de Montpellier 1999. http://memoireonline.free.fr/memoirepeggy.html (5 April 2005).

Hoffmann, Stanley. "The high and the mighty." The American Prospect 13 (2003): 19-37.

Huntington, Samuel. Who Are We: The Challenges to America's National Identity. New York: Simon \& Schuster, 2004.

Kaufman, Eric. "American exceptionalism reconsidered: Anglo-Saxon ethnogenesis in the 'Universal' Nation, 1776-1850." Journal of American Studies 33 (1999): 437-457.

Kersch, Ken. "Multilateralism comes to the courts" The Public Interest 157 (2004): 5-33.

Lakoff, Robin T. "The rhetoric of the extraordinary moment: the concession and acceptance speeches of Al Gore and George W. Bush in the 2000 presidential election.” Pragmatics 11 (2001): 309-327. 
Lipset, Seymour M. American Exceptionalism: A Double-Edged Sword. New York: WW Norton, 1996.

Mason, David. "Commentary on 'We hold these truths to be self-evident."' 2005. http://www.duke.edu/eng169s2/group1/lex3/self-ev.htm (4 April 2005).

Mauk, David and John Oakland. American Civilization: An Introduction. London: Routledge, 1997.

McClay, Wilfred M. "The soul of a nation.” The Public Interest 155 (2004): 24-38.

Mohlo, Anthony and Gordon S. Wood, eds. Imagined Histories: American Historians Interpret the Past. Princeton: Princeton University Press, 1998.

Moore, Roy. S. "Court transcript of the trial of Chief Justice Roy Moore-12 November 2003.” 2003. http://www.chuckbaldwinlive.com/RoyMoore_transcript_full.html (5 April 2005).

Moss, Kenneth B. "Reasserting American exceptionalism-confronting the World. The National Security strategy of the Bush administration." Internationale Politik und Gesellschaft 3 (2003): 135-155.

Murray, Bruce. "With 'God on our side?' How American 'Civil Religion' permeates society and manifests itself in public life." 2005. http://www.facsnet.org (30 March 2005).

Niebuhr, Reinhold. The Irony of American History. New York: Charles Scribner's Sons, 1952.

Rights and Humanities. "What is the source of human rights?" 2003. http://www.rightsandhumanity.org/randhd/default.asp?ID=19\#1 (5 April 2005).

Rios, Delia M. "The revival of American exceptionalism." In Newhouse News Service 2003: 18-41. http://www.newhousenews.com/archive/Rios062703.html (4 April 2005).

Rogers, Daniel T. "Exceptionalism." In Imagined Histories: American Historians Interpret the Past, edited by Anthony Mohlo and Gordon S. Wood, 6-27. Princeton: Princeton University Press, 1998.

Sellevold, Martin. "A look at American exceptionalism." Australian Rationalist 65 (2003): 46-48.

Smith, Rogers. "American conceptions of citizenship and national service." In New Communitarian Thinking, edited by Amitai Etzioni, 55-77. Charlottesville: University Press of Virginia, 1995.

Solomon, Norman. The Twain That Most Americans Never Meet. 2000. http://www.alternet.org/story/831 (30 March 2005).

Stearns, Monteagl. Talking to Strangers: Improving American Diplomacy Abroad. Princeton: Princeton University Press, 1996.

Steinmo, Sven. "American exceptionalism reconsidered: culture or institutions?" In The Dynamics of American Politics: Approaches and Interpretations, edited by Larry Dodd and Calvin Jillson, 61-88. Boulder: Westview Press, 1994. 
Tomi, Leena M. "Critical analysis of American representations of Russians." Pragmatics 11 (2001): 262-283.

Welch, Terry. "Bush's claims to philosophies unfounded." Kansas State Collegian 2000: 44-65.

http://www.kstatecollegian.com/issues/v105/fa/n015/opinion/opn.welch.html (4 April 2005).

Winthrop, John. A Model of Christian Charity. Boston: Collections of the Massachusetts Historical Society, 1838.

Wolfson, Adam. "Conservatives and neoconservatives." The Public Interest 157 (2004): 87-99.

Zulhuda, Sonny. "General survey on human rights. A comparative perspective." 2005. http://islamic-world.net/islamic-state/right_survey.htm (5 April 2005).

\begin{abstract}
About the author
Olaf Du Pont is a Ph.D. candidate at the University of Ghent, Belgium. His interests are in intercultural pragmatics, cultural aspects of translation and socioliguistics. He has also published on classical and modern rhetoric, culture and society.
\end{abstract}

